\title{
Of Phagocytes and Men: Tolstoy's Response to Mechnikov and the Religious Purpose of Science
}

\begin{abstract}
Metaphor is perhaps best thought of as a tension between the imagined and the real worlds. Both worlds are a necessary part of creative thought.
\end{abstract} - Peter H. Niebyl (156)

$\mathrm{O}$ N MAY 30, 1909, the world-famous pathologist and recent Nobel Prize winner Ilya Ilyich Mechnikov (1845-1916) traveled to Iasnaia Poliana to meet Lev Tolstoy. This first and only meeting between the pair was the culmination of many years of intellectual exchange and, at times, angry debate about the purpose of science, art, and religion. There were also more personal ties. Mechnikov's brother, Ivan Ilyich, had served as the model for the protagonist of Tolstoy's The Death of Ivan Ilyich (Gusev 88; Polnoe sobranie sochinenii commentary 26: $680,687) .{ }^{1}$ Although Tolstoy had not met Ilya Ilyich, he was well acquainted with his scientific writings and had written about him in articles, diary entries, and letters. Mechnikov, in turn, was an ardent admirer of Tolstoy's literary works but deeply troubled by his writings on science. Mechnikov devoted an entire article to a rebuttal of Tolstoy's article "On the Purpose of Science and Art" ("O naznachenii nauki i iskusstva," 1887) ${ }^{2}$ - a rare move for a natural scientist. Tolstoy then wrote another article, "On Science and Art" ("O nauke i iskusstve," 1901-03), taking on his detractors and reaffirming his arguments (see PSS 30: 509). In addition to this journalistic polemic over the value of scientific pursuits, Mech-

\footnotetext{
${ }^{1}$ Unless specifically indicated, all references to Tolstoy are to the Polnoe sobranie sochinenii (Iubileinoe izdanie), hereafter abbreviated PSS. Unless otherwise noted, all translations are my own, except for What Is Art?, for which I have used the Maude translation (English page numbers are provided after the Russian in the citations).

${ }^{2}$ It is possible that the article was published even earlier, but this is the first edition I was able to find (thanks to the help of Liladhar Pendse). Tolstoy also wrote "Science and Art" ("Nauka i iskusstvo," 1890-91), but it is unclear whether any version of this was published at the time, and it seems unlikely that Mechnikov could have read it.
} 
nikov wrote about Tolstoy in The Nature of Man: Studies in Optimistic Philosophy (1903), in which he surveyed different philosophers' responses to the idea of death, before offering his own scientific theory on overcoming suffering and prolonging life (122-25). Tolstoy, who had read Etudes sur la Nature Humaine in 1903 (PSS 55: 599), had only spite for this theory, as numerous diary entries attest.

In coming to Iasnaia Poliana, Mechnikov hoped to engage Tolstoy directly regarding their disagreement about science and religion. As he recorded in his memoirs, "for a long time I had been interested in Tolstoy not only as a brilliant writer, but also as a man who was striving to answer some of the most universal questions that concerned thinking humanity" (Stranitsy vospominanii: sbornik avtobiograficheskikh statei 128). He wanted Tolstoy to acknowledge the importance of scientific study in answering these questions. ${ }^{3}$ Tolstoy, in turn, hoped that Mechnikov would acknowledge the importance of a religious perspective. Based on the four extant memoir accounts of the visit, it is clear that the pair never fully found common ground. ${ }^{4}$ Putting a fairly positive spin on the visit, Mechnikov wrote: "Tolstoy noted that at the end of the day our worldviews coincide, but with this difference: he takes a spiritual perspective, and I take a material one" (Stranitsy vospominanii 131). Tolstoy's impression of the visit was far more negative: "Of religionnot a mention, clearly a rejection of what's considered religion and lack of understanding and lack of desire to understand what religion is" (PSS 57: 77).

This meeting between two of the world's most famous public figures-one a scientist, the other a creative writer - is relatively well known. But little has been written on the Tolstoy/Mechnikov polemic leading up to the meeting. At the heart of the polemic was the complex interrelationship between science and literature in the late nineteenth century, a period when the distinction between literary and scientific discourse was not yet clearly defined. As Gillian Beer has demonstrated in her study of Darwin, "in the mid-nineteenth century, scientists still shared a common language with other educated readers and writers of their time" and "in their texts drew openly upon literary, historical and philosophical material as part of their arguments" $(4,5)$. Science relied on metaphor; literature, in turn, drew on scientific ideas as metaphors for the political, social, and psychological phenomena it was engaging. ${ }^{5}$

For Mechnikov, phagocytic theory (which won him the Nobel Prize) was not just a matter of white blood cells and inflammation; it embodied positive collaboration within an organism. He turned to metaphor to describe phagocytosis, referring to his phagocyte defenders of the body as "an army hurling itself against the

\footnotetext{
${ }^{3}$ Alfred Tauber suggests that Mechnikov used his science to help form his philosophical outlook: "He did not naively adopt a preconceived metaphysical scheme to a scientific problem, but mutually reformulated his scientific inquiry with his philosophical orientation. His philosophical development mirrored his scientific findings - each helped frame the other" (22). For Mechnikov, the key idea would be harmony and disharmony, with his early, pessimistic years focused on the latter and his later work focused on the former.

${ }^{4}$ Impressions of the meeting were recorded by Tolstoy in his diaries (57: 77), by Mechnikov (Stranitsy vospominanii: sbornik avtobiograficheskikh statei 128-41), by Mechnikov's wife, Olga (199-205), and by the pianist A.N. Gol'denveizer, who was visiting the Tolstoys at the time (267-72). S.P. Spiro also interviewed Tolstoy about the meeting on the following day (33-36).

${ }^{5}$ Peter Niebyl discusses the centrality of metaphor to the creative process in the epigraph to this essay.
} 
enemy" (Rather 145). ${ }^{6}$ This purposive view of phagocytes engaged in a Darwinian struggle with an invading force gave his theory an almost moral component (Todes 86) that rankled some scientists, ${ }^{7}$ but that, paradoxically, Tolstoy failed to acknowledge in Mechnikov's writings. When Tolstoy himself ultimately turned to phagocytes as a metaphor in his fiction, he thought in even broader terms than Mechnikov, making the phagocyte a model for the ideal moral life.

Tolstoy and Mechnikov's disputes over science and morality fit into a much larger European debate at the turn of the twentieth century. Gregory Radick has argued that, in addition to threatening people's core beliefs about origins and the role of God, Darwin made "the politics of Malthusianism ... part of the politics of evolution" (3), and this politicization of science raised essential moral questions about the role of the struggle for existence and natural selection in improving the human race. Tolstoy addressed Darwinian thought in Anna Karenina, where he rejected scientific logic as a source of knowledge about the meaning of human life. ${ }^{8}$ Thomas Henry Huxley and Herbert Spencer emphasized Malthusian struggle in their writings, while Peter Kropotkin put forth a theory of mutual aid that offered a radically positive take on the effects of scarcity and struggle. On the literary front, William Morris's News From Nowhere (1890) offered a utopian vision of evolution's endpoint for humanity, while writers like H.G. Wells and George Bernard Shaw provided more sober cautionary tales. At the same time, Wells and Shaw, life-long friends and rivals, saw a potentially positive role for science in improving and prolonging life, much as Mechnikov himself would suggest in his Optimistic Studies. A darker influence was Max Nordau, whose bestselling Degeneration (1892) reinforced humanity's helplessness in the face of Darwinian "devolution." In his book, Nordau labeled Tolstoy's conception of life "a form of the phenomenon of degeneration," taking Tolstoy to task for making science "the great enemy" $(145,161)$. In the context of these larger debates about the role of science, Tolstoy's response to Mechnikov appears even more idiosyncratic and antiquated, as he refused to accept the ways scientific advances were reshaping not only humanity's present, but also its potential future path.

This essay will address the intellectual ties between Tolstoy and Mechnikov, as well as the tension between Tolstoy's journalistic and fictional responses to Mechnikov's theories. Tolstoy's antagonism to many aspects of science, which so upset Mechnikov, has been well documented, and Mechnikov's theories were not exempt from Tolstoy's scorn, poured out in essays, diary entries, and letters. However, in his last novel, Resurrection (1899), Tolstoy used Mechnikov's phagocytic theory as a metaphoric basis for the novel's moral philosophy. In so doing, he demonstrated one way of creating the synthesis between science and religion that he had been calling for in his journalistic articles.

\footnotetext{
${ }^{6}$ Andrew Leak points out that George Perec used the phagocyte as a metaphor for the process of literary appropriation, literally "to phagocyte," which works as a pun in French on the word citer: "When he phago-cites a passage of Flaubert or of Kafka, the 'original' is destroyed by being wrenched bodily from its organic context and absorbed into a new one, but it is also acknowledged and resurrected inasmuch as it provides the point of departure for something new" (145).

${ }^{7}$ In 1897, the American pathologist William Welch cautioned against "all ideas which introduce, even unconsciously, the conception of something in the nature of an intelligent foresight on the part of participating cells" (54-55).

${ }^{8}$ I discuss Tolstoy's response to Darwin in Anna Karenina and War and Peace in "Darwin in the Novels: Tolstoy's Evolving Literary Response," Russian Review (forthcoming 2017).
} 
TOLSTOY, MECHNIKOV, AND THE RELIGIOUS PURPOSE OF SCIENCE / 299

\section{Scientific Polemics}

Mechnikov won the Nobel Prize (1908) as the founder of phagocytic theory. From the beginning of his career as a zoologist, he had had a strong interest in Darwin and, through his research, he became convinced that the way phagocytes (white blood cells) protect an organism from harmful foreign microbes within the body parallels the "struggle for existence" that, according to Darwin, takes place between individuals of the same or different species (Todes 82-103). Mechnikov reached this conclusion by applying the knowledge he had acquired from studying parasites and evolution to his research on intercellular digestion. As he later explained to a non-scientific audience in 1908, while looking through his microscope at mobile cells in transparent star-fish larva, "It struck me that similar cells might serve in the defense of the organisms against intruders [and] I said to myself that, if my supposition was true, a splinter introduced into the body of a star-fish larva, devoid of blood vessels or of a nervous system, should soon be surrounded by mobile cells as is to be observed in a man who runs a splinter into his finger" (qtd. in Todes 94-95). And such was the case. Mechnikov's original essay on the topic, "Researches on the Intracellular Digestion of Invertebrates" ("Issledovaniia o vnutrikletochnom pishchevarenii u bespozvonochnykh"), first published in German in 1883, concludes that "the power of intracellular ingestion and absorption is used as a protection against harmful bodies arising within an organism on reaching it from without" (111). As a result, "The great advances made in Pathological Science during the past few years cannot fail to benefit pure Zoology, which will, in its turn, help to solve the problems of Medicine by establishing a Comparative Pathology, based on the doctrine of Evolution" (111).

Despite the fact that Mechnikov's stated goals were broad and involved unifying various fields of science (something Tolstoy theoretically should have approved of), it will come as little surprise that Tolstoy had no patience for his theory. While Tolstoy believed science was necessary and important, he was critical of several aspects of the way it was being practiced or applied in the late nineteenth century. These criticisms focused on the over-specialized nature of scientific study, its distance from everyday concerns, the lack of a moral component to scientific inquiry (and materialism generally), and the vast resources being devoted to research that - to his mind-seemed frivolous and self-indulgent. Tolstoy stubbornly refused to accept that science could play an important role in analyzing the workings of life without weighing in on life's meaning. In his Confession (1882) he complained about the "important and serious tone of science as it declares conclusions that have nothing in common with the questions of human life" (PSS 23: 16); indeed, "if you turn to the divisions of knowledge that try to answer the questions of life- to physiology, psychology, biology, sociology-you encounter an indefensible pretension to solve irrelevant questions and continual contradictions between one thinker and another, and even one thinker contradicting himself" (PSS 23: 18).

Tolstoy believed that any science that was not directly "in service of the people" (dlia pol'zy naroda) was "untrue" (neistinnyi). Despite the fact that understanding the mechanism of phagocytosis had direct implications for medicine and, consequently, for improving the health of the common worker, Tolstoy was not willing to take the extra step in acknowledging that knowledge of small particles that were invisible to the naked eye could improve people's lives. To him, the study of 
such microbes and cells was an idle indulgence for scientists with too much time on their hands (by this point he considered only manual labor to be true work). Thus, in "On the Purpose of Science and Art," Tolstoy rails against "science for science sake" ("nauka dlia nauki"): "botanists found a little cell [kletochku], and in little cells protoplasm, and in protoplasm still something else, and in that little thing still something else. It is evident that studying these things will not conclude any time soon because, evidently, there can be no end, and therefore scholars do not have any time to study the things that are necessary for people" (399). Complaining that "science and art stipulated for themselves the right to be idle and to use others' labor," he explains: "If there are telephones and telescopes, poems, novels, theaters, ballets, symphonies, operas, picture galleries, etc., then from all of this the life of the worker has not improved because all this, as a result of the same unfortunate chance, is inaccessible to him" (394, 397).

Similarly, in "Science and Art" ("Nauka i iskusstvo," 1890-91) — another in the series of (often unfinished) articles he composed while working out the ideas for What Is Art? - he wrote that, although tremendous energy had been spent on scientific and artistic pursuits, "those who carry the entire burden of this production on their shoulders - precisely the larger mass of the people-do not need these museums, galleries, universities, conservatories, academies" (PSS 30: 238). In his view, the common man was breaking his back and wasting his strength in service of frivolous pursuits that were only entertainment for the leisure class (his description of the tyrannical conductor leading an opera rehearsal in What Is Art? makes a parallel point, if in more graphic terms).$^{9}$ Mechnikov's phagocytes fell foul of this line of argument: "to a simple, uneducated man it cannot be totally clear that our knowledge of phagocytes, whether they exist or not, will not make any difference. To a simple man, scared by terrible, unheard of words that scholars use more of the emptier the business is, it is not always apparent that reflections on phagocytes and their excrement are unnecessary trifles." ${ }^{10}$ Tolstoy made the same argument about most art, suggesting that its uselessness was even more obvious.

Mechnikov was so disturbed by Tolstoy's attack on science in "On the Purpose of Science and Art" that he devoted an entire article, "The Law of Life" ("Zakon zhizni," 1891), to dismantling Tolstoy's claims. He begins by making an assertion about Tolstoy's teachings: "at the basis of them lays the purely rational, naturalhistorical principle: man is an animal machine, uniquely designed and suitable for precisely defined activities" ("Zakon zhizni" 217). In "On the Purpose of Sci-

\footnotetext{
${ }^{9}$ Tolstoy in fact advocated a revised division of labor in which even great scientists and artists did no more than a few hours of mental labor a day and devoted the rest of their time to physical labor (Mechnikov breaks down the logic of this division in "Zakon zhizni" 231). In this discussion of labor and how one should spend one's time, Tolstoy of course turned to his own life. He divided up the twenty-four hours of his day into eight for sleep, five for intellectual work (umstvennaia deiatel'nost'), and (he claimed) the remaining eleven for manual labor ("O naznachenii nauki i iskusstva" 433). As Bakhtin points out, in the scene in Resurrection in which Nekhlyudov wakes up in bed, Tolstoy draws attention to "the huge amount of other people's labor that every trivial detail of this comfort swallows up, emphasized by the words - 'it was prepared,' 'it was cleaned,' 'the shower was prepared,' 'his clothes brushed and lying ready for him on a chair,' 'the parquet floor which had been polished by three peasants the day before'" (253). The novel thus makes the same point as these articles on science and art.

${ }^{10}$ This sentence is missing from the version of "Science and Art" that appears in Tolstoy's PSS. Here I cite the website Fundamental'naia elektronnaia biblioteka "Russkaia literatura i fol'klor."
} 
ence and Art," Tolstoy draws his examples and evidence from the animal world, frequently making analogies to humans: a bird is built to fly, and when it does so it is satisfied (udovletvorena); in the same way (tochno tak zhe) humans are made to walk, lift, work with their fingers, eyes, ears, etc., and when they do these things they are satisfied (218; cf. Confession, PSS 23: 42). Tolstoy also uses this example to help justify the need for manual labor as one of the foundations of happiness. However, as Mechnikov points out, Tolstoy then contradicts this line of argument: "In his opinion, true science can be recognized as such only if it immediately poses and answers the question 'what does the purpose and good of all people consist of'; and since for this there's no need for studying insects, worms, protoplasm, etc. (Count Tolstoy forgets that his own main principle of action is based precisely on comparison with the functions of animals), he considers the study of these subjects 'idle and harmful entertainment'" (220). ${ }^{11}$ Mechnikov also dismantles point-by-point Tolstoy's naïve claims by examining the actual scientific facts that underlie them.

Tolstoy, in turn, had withering criticism for Mechnikov's later theories about aging and death, perhaps all the more pointed because it was confined to diaries and letters, rather than published essays. After his work on intercellular digestion, Mechnikov turned his attention to the aging process, seeking ways to prolong life and reduce suffering. He suggested that natural death (as opposed to death from infectious disease) among old people is rare and probably caused by auto-intoxication (Prolongation of Life 120). After reviewing contemporary studies of the role of the large intestine, Mechnikov suggested that "the intestinal microbes or their poisons may reach the system generally and bring harm to it. I infer from the facts that the more a digestive tract is charged with microbes, the more it is a source of harm capable of shortening life" (72). Indeed, "the duration of life of mammals has been notably shortened as the result of chronic poisoning from an abundant intestinal flora" (72). After discussing lactic acid and fermented foods and drinks that could diminish the harmful microbes in the large intestine (151-56, 161-83), he then concluded: "If it be true that our precocious and unhappy old age is due to poisoning of the tissues (the greater part of the poison coming from the large intestine inhabited by numberless microbes), it is clear that agents which arrest intestinal putrefaction must at the same time postpone and ameliorate old age" (182). In The Nature of Man, he even claimed that the whole of the large intestine was "superfluous" and that its removal would "be met with happy results," citing several examples of patients who had undergone such a surgery (69).

Tolstoy completely rejected this theory. In a 1902 diary entry, he noted bluntly: "I read Mechnikov's article in The Russian News and was outraged" (PSS 54:

11 "Zakon zhizni" was first published in Vestnik Evropy 5: 9-10 (sentiabr'/oktiabr' 1891): pp. 228-60. Mechnikov also dismantles Tolstoy's naïve logic about birds' need for flight, pointing out numerous flightless species, and challenges the idea of "satisfaction" ("udovletvorenie") in relation to animals (222-23). Tolstoy later commented in "On Science and Art" that "loving science and art ... I tried to show that not all the activities that take place in our era under the name of science and art are in essence good activities and worthy of respect; and the people to whom my comments were primarily addressed decided that I was an enemy of science and art, and consequently that it was not worth paying attention to my arguments" (PSS 30: 240). Although these words were clearly not intended to refer to Mechnikov only - Tolstoy had made a similar claim before the polemic with Mechnikov ("On the Purpose" 407-08) — the frustrated pathologist would certainly have been one of those "people." 
301). ${ }^{12}$ The next year, in a humorous diary entry, he commented: "I read Mechnikov's article again on the same topic: that if you cut out the rectum, people will no longer think about the meaning of life and will become as stupid as Mechnikov himself. No, without jokes. His idea is that science will improve the human organism and free it from suffering, and then it will be possible to find the meaning, the purpose of life. Science will reveal it. Well, how should everyone live before then? After all, billions have lived with rectums" (PSS 54: 157). For Tolstoy, Mechnikov's scientific approach was overly focused on minor, insignificant details and overlooked man's spiritual side. In 1904 he thus commented in his diary:

Mechnikov has thought up how, by cutting out the rectum or rummaging around in the ass, to render old age and death harmless. As if without him and before him no one has thought of this. Only he now realized that old age and death are not completely pleasant. People thought of this before you, Mister Mechnikov, and not such childish minds like yours, but the greatest minds in the world, and they worked on and resolved the question of how to render old age and death harmless, but they worked on this question intelligently, not like you: they sought the answer to the question not up their ass, but in the spiritual nature of man." (PSS 55: 54)

Tolstoy also believed that attempting to eliminate suffering was misguided: "For pain Sasha took morphine. Our nanny didn't approve: suffering is necessary when sent by God. But Mechnikov wants to destroy not only suffering, but also death. Isn't he just a pathetic, spoiled child in comparison with the folk wisdom of the old woman?" (PSS 55: 139).

Yet Tolstoy continued to follow Mechnikov's work. As late as July 1909, he noted: "For two days I read a bit of Mechnikov's book and was horrified at its light-mindedness and straight-up stupidity" (PSS 57: 97). If one were to take Tolstoy at his word, it would seem that he had no respect for any of Mechnikov's theories and believed him to be a total fool. Yet if that were the case, why did he continue to read Mechnikov? What did he find in the writings of this "spoiled child" beyond reasons for "outrage"?

\section{Resurrection and Tolstoy's Synthesis of Science and Religion}

As was often the case with Tolstoy, what he wrote about Mechnikov in his nonfiction differed markedly from the way he responded to Mechnikov in his fiction. Tolstoy drew on Mechnikov's phagocytic theory in Resurrection, not as a scientific theory worthy of scorn, but as a structural metaphor for the religious outlook he was advocating. In human beings, the function of phagocytes is to protect the body from harmful foreign particles. In Resurrection, Tolstoy depicts the world as one living organism, and the highest purpose for an individual in the novel is to become a "human phagocyte" devoted to supporting all the ailing parts of that living whole. Mechnikov's phagocytic theory thus offered Tolstoy a model for addressing the relationship between part and whole, between individual and collective, that was central to his thought from War and Peace through his late religious writings.

${ }^{12}$ Tolstoy is referring to the correspondence of K.V. Arkadansky, published in Russkie vedomosti 7 March 1902 (No. 65): "Professor I.I. Mechnikov o vozzreniiakh na chelovecheskuiu prirodu" (see commentary in PSS 54: 508). The article includes one mention of Tolstoy and his fear of death (Russkie vedomosti 7 March 1902, p. 3). 
The role of science has not figured prominently in the scholarship on Resurrection, a novel that breaks the traditional mold of fallen woman tales and is usually seen through the lens of the reformed-prostitute/reformed-landowner theme. The heroine, Katyusha Maslova, has been seduced by Dmitri Nekhlyudov and has fallen into prostitution before the novel begins. The novel opens with Nekhlyudov reencountering Maslova while serving as a member of the jury at her trial for a murder she did not commit. After she is sentenced to Siberia through a technical error, Nekhlyudov realizes the wrong he has done her, and this leads to his spiritual awakening. Nekhlyudov rejects his gentry privilege and gives his land to his peasants, secures a pardon for Katyusha, and follows her to Siberia, where she ultimately rejects his offer of marriage in favor of one from a fellow prisoner, Vladimir Simonson.

The idea of phagocytes is introduced into the novel by Simonson, who uses the concept as a justification both for a personal religion based on thinking of the world as a living organism and for devoting his life to the service of the weak and suffering parts of this whole. Although the word "phagocyte" appears only in the passage where the narrator explains Simonson's religion, I believe that this metaphor can be applied to the moral outlook Tolstoy is advocating throughout the book. Not only Simonson but also Nekhlyudov, Marya Pavlovna, and Katyusha become metaphoric "phagocytes" by the novel's conclusion.

The importance of Simonson's phagocyte metaphor is linked to his role as a positive ideal, a New Man much like Rakhmetov in Chernyshevsky's What Is to Be Done? (1863), although there is no reason to believe Rakhmetov served as a model (Tolstoy in fact despised Chernyshevsky, but still polemicized with him). ${ }^{13}$ Simonson lives entirely by his principals: "Having decided while in the gymnasium, that his father's income as a former quartermaster was earned dishonestly, he informed his father that he should give his fortune to the people," and, when his father did not listen, he left home, withdrew from the university, "joined the narodniki [members of a populist social movement], became a village teacher and bravely preached to his students and the peasants all that he considered just and repudiated what he considered false" (PSS 32: 369).

Based on these convictions, Simonson "formulated for himself a religious teaching that governed all his activity." For Tolstoy, it is essential both that Simonson lived by religious principles and that he himself thought them up, rather than having accepted them from some external authority such as science or divine writ (Tolstoy's attack on the Orthodox Church as such an authority in the novel is notorious): $:^{14}$

This religious teaching consisted in the belief that everything in the world is alive, that there is nothing dead, that all the objects that we consider dead or inorganic are in fact only parts of an enormous organic body that we cannot comprehend, and that consequently man's task, as a part of this enormous organism, consists in sustaining the life of the organism and all its living parts. (PSS 32: 369-70)

${ }^{13}$ This is in keeping with Bakhtin's suggestion that Resurrection is a socioideological novel like What Is to Be Done? and Herzen's Who Is to Blame? (242). Bakhtin notes that the criticism of reality in such novels "is also accompanied by - or interrupted by-direct proofs of the thesis in the form of abstract arguments or sermonizing, and sometimes by attempts to depict a utopian ideal" (243). I believe Simonson is such an "interruption."

${ }^{14}$ To find "what your purpose and well-being consist of, and the purpose and well-being of all humanity, of the whole world," Tolstoy argued that one must listen to the voice of one's conscience. Tolstoy ridiculed the idea that one should get the answer from a man with a diploma who has been looking in a microscope at amoebas and cells ("O naznachenii nauki i iskusstva" 414). 
Tolstoy made similar statements in his diaries and letters, using the living organism as a metaphor for society. For example, in 1905 he wrote:

The closer the state of a society is to an organism, the more tightly its parts are bound together in such a way that each part is concerned about the good of the whole [tseloe], the more the form depends on the content and vice versa. In the union of people when all members united together participate in the decisions commonly for all and freely submit to them, as happens in small communes, the form which flows from the nature of the union, from the content, will always be the same: the equality of all members and the free fulfillment of positions established by common agreement. (PSS 76: 39-40) $)^{15}$

In other words, Tolstoy used the organism metaphor for structuring society as a positive, anarchic alternative to governments where a few ruled over the many.

However, Tolstoy also saw a negative side to viewing the world as a single organism, especially within the realm of science. In "On the Purpose of Science and Art" he wrote that, in a scientific context, such a theory was harmful because it reinforced the idea "that the division of activity that exists in human society is organic, i.e. necessary, and consequently, that the unjust conditions should be regarded ... as an incontrovertible fact supported by a general law" (378; cf. 386). Tolstoy later reformulated these arguments in What Is Art? (1897), where he argued that "one side of science [including theology, philosophy, history, and political economy] is chiefly occupied in proving that the existing order is the very one which ought to exist, that it has come into existence and continues to exist by the operation of immutable laws not amendable to human will, and that all efforts to change it are therefore harmful and wrong" (PSS 30: 187 / 182).

The theory that the world is a single, living organism thus provides an idea toward which, in his essay writing, Tolstoy takes one stance, whereas in his novel he suggests the opposite. For Simonson, who came to this theory through his own reasoning and who relates to it as a religious - rather than scientific-principle, interconnectivity is a positive ideal. It answers the most important questions (for Tolstoy): What must I do and how must I live? Based on his personal religious outlook, Simonson is against war (like Tolstoy), against corporal punishment (like Tolstoy), and against "any killing not only of people, but also of animals" (like Tolstoy). Consequently, he lives as a vegetarian and does not use the skins of "killed animals" (PSS 32: 364). Based on this "religious" worldview (which for Tolstoy really means "ethical"), Simonson also theorizes that "procreation was only a lower function of man, a higher function was the service of already existing life," finding "support for this thought in the existence of phagocytes in the blood. Unmarried people, in his opinion, were such phagocytes whose purpose was to help the weak and ill parts of the organism" (PSS 32: 370).

In this context, phagocytic theory reinforces Tolstoy's other views. Like all of Tolstoy's late thinking, however, it is predicated on ignoring the specificity and essential identity of each of the individuals or "parts" in need of care. By the end

${ }^{15}$ Letter to F.A. Strakhov, 5-6 October 1905 (qtd. in Gustafson 400; I am using his translation). Gustafson claims that "the individual and society are related as cell to body" (400), but, interestingly, Tolstoy himself never uses the "cell state" metaphor, even though it was very popular, due in part to the writings of Rudolf Virchow (1821-1902). Tolstoy mentions Virchow only once in the Polnoe sobranie sochinenii (17: 369), where he appears in the list of people who would make up the composite figure of the natural scientist (estestvennik) in the unfinished work "Interlocutors" ("Sobesedniki,"1877-78). 
of the 1890s, Tolstoy also opposed sexual relations, even in marriage. ${ }^{16}$ Moving beyond his earlier family ideal, he had come to believe, like Simonson, that people had a duty to serve not only their "close ones" (blizkie), but all of humanity. Indeed Tolstoy's alter ego in Resurrection, Nekhlyudov, is resurrected specifically through coming to understand that he must renounce his earlier ideals of romantic love and family happiness and must instead serve the sufferers around him. He progresses from poetic visions of romantic love, to animal sensuality, to the idea of marriage and family, and finally to the broader task of helping the needy.

Nekhlyudov's spiritual rebirth is also closely bound up with the broader worldview Tolstoy expounds in the novel. Resurrection opens with a description of the destructive, suffering-filled world created by people juxtaposed to the wonders of nature: "Though the people tried hard to disfigure the land on which they crowded, several hundred thousand gathered in one not-large area, though they hammered rocks into the earth so that nothing grew in it, though they cleared away every blade of grass that had broken through, though they filled the air with smoke from coal and petrol, though they cut down the trees and kicked out all the animals and birds, spring was spring even in the city" (PSS 32: 3). Failing to appreciate the joyful harmony of nature, people, Tolstoy suggests, create for themselves their own suffering:

Happy were the plants and birds and insects and children. But people — big, adult people — did not cease to deceive and torment themselves and each other. These people considered sacred and important not this spring morning, this beauty of God's world given for the joy of all creaturesbeauty that disposed the world to harmony and love-but instead considered sacred and important what they themselves had thought up in order to dominate over each other. (PSS 32: 3-4)

Here, in the first lines of the novel, Tolstoy depicts the natural world as a united and harmonious whole (a living organism) and humanity as disrupting this organic unity. This worldview lays the foundation for the introduction of phagocytic theory later in the novel. People's failures stem from thinking of themselves as individuals, rather than interdependent parts of this larger whole, as Simonson does. By including "children" in the list of the happy, Tolstoy, a Rousseau disciple, suggests that this failure is not inherent to man, but is brought on by the corrupting influence of society.

Throughout the novel Tolstoy systematically contrasts the corruption and suffering of human society with the purity of the world of nature. Nekhlyudov's early, pure romance with Katyusha is set in the context of an unspoiled nature and involves rising before dawn, swimming in the river under the mountains, returning while the dew still lies on the grass and flowers, wandering in the woods and fields, riding or boating after lunch, and wandering in the garden in the moonlight, unable to sleep from experiencing the "too greatly agitating joy of life" (PSS 32: 44). During this phase, Nekhlyudov thinks of women only in the capacity of possible wives. He is in a state of innocence and purity like the natural world around him.

After Nekhlyudov's life becomes corrupted, he must gradually seek to regain his place within this natural harmony. Reflecting on the falsity of his life on the

${ }^{16}$ Tolstoy presents these ideas in "The Kreutzer Sonata" through the speeches of Pozdnyshev, his wife-murdering, unstable narrator. He then reaffirms these ideas in his "Afterwards to "The Kreutzer Sonata'” (PSS 27: 79-83). 
night after Katyusha's conviction, Nekhlyudov prays to God to purify (ochistit') him (PSS 32: 103), opens a window, looks out at the "garden illuminated by the moon," breathes in the "enlivening fresh air," and says "How good! How good, my God, how good!” (PSS 32: 104). Similarly, when Nekhlyudov finds himself entangled in increasingly complex questions in carrying out his intention to give his land to the peasants, he escapes these troubled thoughts by again opening a window, and "together with the fresh air and moonlight poured in the croaking of frogs, interrupted by the trills and whistles of nightingales from the park, one distant and one close under the window in a blossoming lilac bush" (PSS 32: 203). Nature is in harmony. Only people fail to understand their place in the Whole.

Tolstoy is not suggesting, however, that one can avoid responsibility by becoming part of this larger, organic whole (see Hudspith 23, 25). Katyusha's trial serves as a powerful reminder of individual responsibility, especially as part of the aggregate. Through carefully delineating the ways in which each person involved in Katyusha's trial helped to bring about her false conviction-one through arriving late because of a catarrh of the stomach; another by hurrying because his lover was waiting; a third through lying about his own guilt on the stand; a fourth through judging her way of life, despite being a client of her brothel; Nekhlyudov through having brought about her fall; the entire jury for seeking a quick consensus and not paying attention to the details of their verdict; and others simply through participating in the unfair legal process-Tolstoy demonstrates that all are implicated, that all are guilty.

At first Nekhlyudov, like everyone else in the court, fails to see (or chooses not to see) the horror of participating in the "justice" system: the suffering of the people caught in the penal system, the dehumanizing effect this system has on the people working in it, and how each person is guilty of causing the suffering involved. However, after the spiritual awakening brought about by the trial, Nekhlyudov tells a servant that Katyusha has been sentenced for murder, "and I did it all" (PSS 32: 118). His "resurrection" thus begins with an acknowledgement of collective guilt. He also declares: "I am guilty, and therefore I want to make amends" (PSS 32: 118). These statements go too far to the opposite extreme of self centeredly taking all guilt for himself. Nekhlyudov's acknowledgement of participation in this collective guilt (even if overstated) directs his future actions, as he accepts the duty of righting the wrongs that have been committed, rather than using the collective as an excuse for abnegating responsibility.

These ideas about interconnectedness and being guilty before all are clearly related to ideas Tolstoy had encountered in his reading of Eastern philosophy. ${ }^{17}$ Tolstoy was impressed by the Buddhist understanding of the unity of life and universal guilt, both of which are highlighted in his adaptation of the Eastern legend "It's you" ("Eto ty") (Milivojevic 7-8). In Tolstoy's version, the wise man in the story (mudrets) explains to his interlocutor: "Look around yourself at all living things and say to yourself: all this is me. All men are brothers, that is, all people in their essence are one and the same person. Before a higher justice there is no evil

${ }^{17}$ For more on the importance of Eastern philosophy for Tolstoy, see Lavrin 135 and Abraham 107-08. Lavrin also notes that the Buddhist outlook was very important to Schopenhauer, whose works Tolstoy greatly admired (135). The pessimism Tolstoy found in Buddhism may be partly based on Schopenhauer's interpretation. Ignatovich provides a list of the works in Tolstoy's personal library related to Buddhism and notes about which ones he read and notated (21). 
that would not be punished. When you lift your hand against your enemy, you hit yourself because the offender and the offended are in essence one and the same" (PSS 34: 139). Here again, we see Tolstoy's desire to make all "parts" or "cells" interchangeable. Yet, if the philosophy Tolstoy puts forward in Resurrection has much in common with his understanding of Eastern religions (here specifically Buddhism), the link with Mechnikov's theory is equally clear. ${ }^{18}$ Although Tolstoy only uses the term "phagocyte" in relation to Simonson, after Nekhlyudov's resurrection, he essentially becomes a human phagocyte, devoting himself to the ailing parts of the whole. Through using this metaphor, Tolstoy demonstrated an important connection between the pathologist's theory and his favorite aspects of the teachings of Buddhism and Hinduism.

Once Nekhlyudov embraces his new role and world outlook, he finds more and more sufferers - parts of the living world-organism - in need of his aid or protection. Before his resurrection, Nekhlyudov lacked a purpose (like most gentry men in Tolstoy's view), but now "It was an astonishing thing that what was needed for himself he could in no way decide, but what needed to be done for others he knew unquestionably" (PSS 32: 225). ${ }^{19}$ When Nekhlyudov stops focusing on his personal achievements and pleasures, and instead begins to think about the people around him, he takes joy in the Christian idea "to feel oneself a servant, not a master" (PSS 32: 226), and he accepts the idea that he is part of the whole with God at its head. With this new Christian version of phagocytic theory as a basis for his moral decisions, Nekhlyudov goes to St. Petersburg to accomplish three tasks: getting a pardon for Katyusha, arranging the question of his estates (that is, helping the peasants), and giving "help to the prisoners who applied to him more and more frequently" (PSS 32: 310).

Similarly, when Nekhlyudov is on his way to the train station before the prisoners depart for Siberia, he turns his attention to a prisoner who has fallen and is dying from sunstroke. The policeman (gorodovoi), clerk (prikazchik), and escort guard (konvoinyi) all discuss the heat, assigning responsibility without taking action, while Nekhlyudov alone tries to alleviate the dying man's suffering by requesting water, giving up his carriage, and promising to pay the driver to transport the man to the police station. Later, he reflects: "And most horrible of all is that he was killed, and no one knows who killed him. But he was killed" (PSS 32: 349). Once again, he senses the interconnectedness and collective guilt of the living organism of which all are a part (see also McLean, "Resurrection” 108).

\section{Replacing the Family Ideal}

For Tolstoy, making the phagocyte his ideal role for people meant turning away from his earlier family ideal. In Resurrection Tolstoy's most enlightened characters no longer aspire to the roles of father and mother. Instead, they subscribe to a new

\footnotetext{
${ }^{18}$ Mechnikov himself was intimately acquainted with Eastern philosophy and devoted the better part of a chapter in The Nature of Man, "Religious Attempts to Combat the Ills Arising from the Disharmonies of the Human Constitution," to Confucianism, Taoism, and Buddhism.

${ }^{19}$ This is a modification of what Levin experiences in Part 8 of Anna Karenina, where he does not know how to help humanity as a whole, only his family. Tolstoy has broadened and depersonalized the sphere in which his characters can and should operate.
} 
conception of Tolstoyan brotherhood, for if all people are siblings, they will give their love and help to their most needy "brothers," not the ones who happened to grow up in the same home (or at least this is what Tolstoy would like to believe). Marya Pavlovna, perhaps Tolstoy's most positive female character in any of his fictional works, has left her family, taken the blame for another's crime, and is being sent to Siberia among the political prisoners. While in the 1860s and '70s Tolstoy envisioned motherhood as the ideal goal for women, in Resurrection he gives women the same calling as men. ${ }^{20}$ Like Simonson, Marya Pavlovna is a human phagocyte. She rejects sexual love and the family: "All the interest of her life consisted in finding occasions to serve others, like a hunter searching for game" (PSS 32: 368). She thus thinks of herself not as an individual, but as part of the whole of humanity. ${ }^{21}$

Tolstoy also uses Nekhlyudov's personal progression in Resurrection to trace the progression through which his own thought about love had passed. Nekhlyudov moves from "first poetic love" to "sensual love" to "the satisfaction of a duty fulfilled" at the idea of marriage to Katyusha to "pity and tenderness" for her and finally to the expansion of this feeling: "Whatever he thought of now, whatever he did, his general mood was a feeling of pity and tenderness, not only for her but for all people" (PSS 32: 372; see also chap. 5 of my Siblings). At the start of the novel, Nekhlyudov considers marrying Missy, a perfectly appropriate choice from society's perspective, but he rejects this idea as a false form of self-gratification. At the end of the novel, when faced with another image of family happiness, he again turns away. After Nekhlyudov dines in the comfort of a general's home in Siberia, the general's daughter takes him to see her sleeping children in the nursery. While the scene seems idyllic - kindhearted nanny, beautiful sleeping two-yearold girl, and young boy-Tolstoy emphasizes the selfishness of this ideal. The mother seeks praise for her children, asking "isn't she beautiful?" ("Khorosha?"), "smiling knowingly" ("mnogoznachitel'no ulybaias'"), and "greedily soaking up" Nekhlyudov's praise of the boy (PSS 32: 430).

Furthermore, while both Tolstoy's earlier novels - War and Peace and Anna Karenina - end with scenes of domestic life and family love, Resurrection calls for a new narrative conclusion. Valeria Sobol has argued that "scientific rhetoric and logic . . . are employed, in literary narratives, to create an alternative to romantic love, while a new 'scientific' model of love's development and its various stages sought by Tolstoy and his contemporaries inevitably entails the problem of the plot" (55). Sobol is here concerned specifically with the stages or progression of love when a character falls in love (its physiological effects), but her point applies equally well to Tolstoy's use of the phagocyte as an alternative model for human connection that replaces romantic love altogether.

\footnotetext{
${ }^{20}$ In this aspect of his thought, Tolstoy actually moves closer to Mechnikov, who attacked Tolstoy's "scientific" justifications for women having different roles. In "Zakon zhizni" Mechnikov argues that "the natural qualities of the female organism suited to childbearing cannot serve even the slightest hindrance to some women finding gratification in striving to devote themselves to the highest spheres of intellectual labor" (239). See also Cruise 283.

${ }^{21}$ Hariet Murav links the phagocytic roles of the desexualized Simonson and Maslova to the philosophy of Nikolai Federov (1829-1903), who believed in the resurrection of ancestors as opposed to the creation of new generations. Murav notes that in the draft of Resurrection Simonson believes in the "necessity of the material resurrection of all the dead," which directly ties his ideas to Fedorov's (42).
} 
Tolstoy's new ideal called for a specific kind of love-impersonal, based on pity rather than affection or passion. Simonson is thus able to love Katyusha and still live up to his teachings: "his love for Katyusha did not destroy this theory, as he loved her platonically, considering that such love not only did not impede his phagocytic activity of serving the weak, but even more strongly animated it" (PSS 32: 370). Clearly, Tolstoy is describing here what he wished he himself could experience. When Katyusha gives up Nekhlyudov (whom she still loves) and chooses to marry Simonson, she is also devoting herself to a life of service rather than romantic love and the family ideal. Her gradual resurrection has been preparing her for this choice, first through rejecting sexual love, then through helping others, both in the hospital and later carrying the daughter of the non-political prisoner who was not allowed to walk with his child.

Tolstoy's new phagocytic ideal in turn generates the need for new plots, as Sobol notes; the culmination can no longer be marriage and the happy home, but must involve some further mission for the protagonist. In the case of Resurrection, Tolstoy looks for a Christian resolution in the Gospels. At the end of the novel, Tolstoy unites the phagocytic teachings of Simonson with Christianity, since both emphasize seeing the self as part of a larger whole. Left alone after Katyusha's rejection, Nekhlyudov turns to the Gospels and decides that

if we were sent here, then it was by someone's will and for something. But we decided that we live only for our own happiness, and it's clear that we are feeling bad, as a worker will feel bad when not fulfilling the will of his master. The will of our master is expressed in these commandments. If people simply fulfill these commandments, then the kingdom of God will be created here on earth and people will receive the greatest good that is possible for them. (PSS 32: 444)

In accepting the teachings he finds in the Gospels, Nekhlyudov chooses the phagocytic life of service. Tolstoy had found a way of synthesizing scientific and religious metaphors.

\section{The Synthesis of Science and Art}

After years of attacking science, Tolstoy used the tools of the enemy, moving phagocytes into the literary realm to reveal their dormant spiritual meaning. But he also embeds a direct critique of scientific thinking in Resurrection via the reflections of Simonson: "If - he wrote - a bacteria observed and studied a person's fingernail, it would consider the person to be an inorganic being. In just the same way we observe the crust of the globe and consider it an inorganic being. This is false" (PSS 32: 364). Scientists, in Tolstoy's view, were too specialized. Focusing on some tiny aspect of the world - invisibly small bacteria, amoebas, or microbesthey did not think about the larger context or significance of their work. In a draft variant for What Is Art? Tolstoy contrasts phagocytes with truly important subjects: "It behooves us only to look around ourselves and we will see that phagocytes, x-rays, and other such trifles are not topics of real science, but precisely the questions of religion, morality, communal living, those same questions that some misguided scholars of the new movement do not even consider scientific" (PSS 30: 421). In the final version he expands this point, claiming that "real science lies in knowing what we should and what we should not believe, in knowing how the associated life of man should and should not be constituted; how to treat sexual relations, how to educate children, how to use the land, how to cultivate it oneself without 
oppressing other people, how to treat foreigners, how to treat animals, and much more that is important for the life of man" (PSS 30: 190 / 185). ${ }^{22}$ Tolstoy believed that scientists fail to see this because, looking in their microscopes, they "do not glance around themselves and see what is truly valuable, they do not see those important questions that surround our life and demand our attention to be solved" (PSS 30: 420). This was his deepest criticism of science.

Tolstoy did not reject science, however. Instead, he argued that it must work together with art: "True science investigates and brings to human perception such truths and such knowledge as the people of a given time and society consider most important. Art transmits these truths from the region of knowledge to the region of emotion. Therefore, if the path chosen by science be false, so also will be the path taken by art" (PSS 30: 186 / 181). ${ }^{23}$ Resurrection demonstrates the symbiosis of science and art for which Tolstoy called. By giving a moral meaning to Mechnikov's scientific theory, Tolstoy (while contradicting his own stated belief that there was no use in studying minutia of the natural world) used the concept of the phagocyte to answer the questions closest to his heart: What must I do and how must I live?

McGill University

\section{Works Cited}

Abraham, J.H. "The Religious Ideas and Social Philosophy of Tolstoy." International Journal of Ethics 40.1 (1929): 105-20. Print.

Bakhtin, Mikhail. "Preface to Vol. 13: Resurrection." Rethinking Bakhtin: Extensions and Challenges. Trans. Caryl Emerson. Ed. Gary Saul Morson and Caryl Emerson. Evanston: Northwestern UP, 1989. 237-57. Print.

Beer, Gillian. Darwin's Plots: Evolutionary Narrative in Darwin, George Eliot and Nineteenth-Century Fiction. Cambridge: Cambridge UP, 1983. Print.

Berman, Anna A. Siblings in Tolstoy and Dostoevsky: The Path to Universal Brotherhood. Evanston: Northwestern UP, 2015. Print.

Cruise, Edwina Jannie. "The Ideal Woman in Tolstoi: Resurrection.” Canadian-American Slavic Studies 11.2 (1977): 281-86. Print.

Gol'denveizer, A.B. Vblizi Tolstogo. Moscow: Gosudarstvennoe izdatel'stvo khudozhestvennoi literatury, 1959. Print.

Gusev, N.N. Lev Nikolaevich Tolstoi: Materialy k biografii s 1881 po 1885 god. Moscow: Izdatel'stvo «Nauka», 1970. Print.

Hudspith, Sarah. "Narrative, Conscience and Judgment in Tolstoy's Resurrection." Tolstoy Studies Journal 17 (2005): 20-34. Print.

\footnotetext{
${ }^{22}$ Tolstoy divides his criticism of the sciences into two categories: "one side of science [social], instead of studying how people should live in order to fulfill their mission in life, demonstrates the righteousness and immutability of the bad and false arrangements of life which exist around us, while the other part, experimental science, occupies itself with questions of simple curiosity or with technical improvements" (PSS 30: 188 / 183). Even in War and Peace, Tolstoy presented a similar argument, albeit in the diary of Pierre Bezukhov during his embrace of Masonry (leaving questionable Tolstoy's own attitude): "The difference between the poor teaching of social science and our holy, all-embracing teaching is clear to me. Human sciences fragment everything in order to understand it, kill everything in order to examine it. In the holy science of the order, everything is known in its entirety and life" (PSS 10: 182).

${ }^{23}$ I have slightly modified Maude's translation of "What Is Art?" for accuracy.
} 
Ignatovich, Alexander. "Echoes of the Lotus Sutra in Tolstoy's Philosophy." Dharma World 25 (1998): 20-22. Print.

Lavrin, Janko. “Tolstoy and Gandhi.” Russian Review 19.2 (1960): 132-39. Print.

Leak, Andrew. "Phago-citations: Barthes, Perec, and the Transformation of Literature." Review of Contemporary Fiction 29.1 (2009): 124-47. Print.

McLean, Hugh. In Quest of Tolstoy. Boston: Academic Studies P, 2008. Print.

—. "Resurrection." The Cambridge Companion to Tolstoy. Ed. Donna Orwin. Cambridge: Cambridge UP, 2002. 96-110. Print.

Mechnikov, Ilia. The Nature of Man: Studies in Optimistic Philosophy. Trans. P. Chalmers Mitchell. New York: G.P. Putnam's Sons, 1903. Print.

—. The Prolongation of Life: Optimistic Studies. Trans. Chalmers Mitchell. New York: G.P. Putnam's Sons, The Knickerbocker P, 1908. Print.

—. "Researches on the Intracellular Digestion of Invertebrates." Quarterly Journal of Microscopical Science 2-24.93 (1 Jan. 1884): 89-111. Print.

. Stranitsy vospominanii: sbornik avtobiograficheskikh statei. Moscow: Izdatel'stvo Akademii Nauk SSSR, 1946. Print.

—. "Zakon zhizni: po povodu nekotorykh proizvedenii gr. L. Tolstogo." Sorok let iskaniia ratsional'nogo mirovozzreniia. Moscow: Nauchnoe slovo, 1913. 216-47. Print.

Metchnikoff, Olga. Life of Elie Metchnikoff, 1845-1916. Boston: Houghton Mifflin Company, 1921. Print.

Milivojevic, Dragan. “Tolstoy's Views on Buddhism.” Leo Tolstoy. Ed. Dragan Milivojevic. New York: Eastern European Monographs, Boulder, 1998. 1-17. Print.

Murav, Harriet. "Maslova’s Exorbitant Body.” Tolstoy Studies Journal 14 (2002): 35-46. Print.

Niebyl, Peter H. "Commentary" to L.J. Rather, "On the Source and Development of Metaphorical Language in the History of Western Medicine." A Celebration of Medical History: The Fiftieth Anniversary of the Johns Hopkins Institute of the History of Medicine and the Welch Medical Library. Baltimore: The Johns Hopkins UP, 1982. 154-56. Print.

Nordau, Max. Degeneration. Lincoln: U of Nebraska P, 1993. Print.

Radick, Gregory. “Dismal Destinies: How London's Socialists Debated the Implications of Darwinism, from William Morris's Vision of an 'Epoch of Rest' to H.G. Wells's Far Future of Degeneration.” Times Literary Supplement 3 July, 2015: 3-4. Print.

Rather, L.J. "On the Source and Development of Metaphorical Language in the History of Western Medicine.” A Celebration of Medical History: The Fiftieth Anniversary of the Johns Hopkins Institute of the History of Medicine and the Welch Medical Library. Ed. Lloyd G. Stevenson. Baltimore: The Johns Hopkins UP, 1982. 135-53. Print.

Sobol, Valeria. "In Search of an Alternative Love Plot: Tolstoy, Science, and Post-Romantic Love Narratives.” Tolstoy Studies Journal 19 (2007): 54-74. Print.

Spiro, S. P. Besedy s L.N. Tolstym. Moscow: Gorodskaia Tipografiia, 1911. Print.

Tauber, Alfred I. Metchnikoff and the Origins of Immunology: From Metaphor to Theory. New York: Oxford UP, 1991. Print.

Todes, Daniel P. Darwin without Malthus: The Struggle for Existence in Russian Evolutionary Thought. Oxford: Oxford UP, 1989. Print.

Tolstoy, Lev. Polnoe sobranie sochinenii (Iubileinoe izdanie). 90 vols. Moscow: Gosudarstvennoe izdatel'stvo "Khudozhestvennaia literatura," 1928-59. Print.

—. "Nauka i iskusstvo." 1890-91. Fundamental'naia Elektronnaia biblioteka Russkaia Literatura $i$ Fol'klor. Web. <http://feb-web.ru/feb/litnas/texts/137/t37-043-.htm>. Accessed 15 Jan. 2015.

—. "O naznachenii nauki i iskusstva." Sochineniia grafa L.N. Tolstogo. Moscow: Tipo-litografiia Vysochaishe utverzhden. Tovarishch I.N. Kushnereva, 1887. 372-446. Print.

—. What Is Art? Trans. Aylmer Maude. Indianapolis: Hackett Publishing Company, Inc., 1996. Print.

Virchow, Rudolf. “Atoms and Individuals.” Disease, Life, and Man: Selected Essays. Stanford: Stanford UP, 1958. 134-55. Print.

Welch, William H. Adaptation in Pathological Processes. Baltimore: Johns Hopkins UP, 1937. Print. 